\title{
A Cognitive Semantic Analysis of Milton's 'Paradise Lost'
}

\author{
By \\ Dr Abbas Fadhil Albayati \\ Assistant Professor of Linguistics \\ Salahaddin University-Erbil \\ College of Languages \\ English Department
}

Email: abbaslutfi@yahoo.co.uk / Mobile: 0750-7176329

\section{Abstract}

Although the field of natural language processing has made considerable strides in the automated processing of standard language, the language of poetry still causes great difficulty. Normally, when we understand human language, we combine the meaning of individual words into larger units in a compositional manner. However, understanding a poem often involves an interpretive adjustment and different conceptualisation strategies of individual words.

This paper aims at exploring the cognitive and semantic bases of Milton's masterpiece 'Paradise Lost' through a combination of theoretical work, corpus analysis, and experimental techniques. The paper hypothesizes that the so-called 'figures of speech' are not mere linguistic devices serving ornamental or literary purposes but correspond to mental 'figures' grounded in cognition. By locating the source of figurativeness in human cognitive make-up, recent research has decisively moved away from the idea that non-literal language constitutes a departure from a linguistic norm. 
A question that is not frequently addressed in the literature is the degree to which the operation of the 'poetics of mind' (Gibbs 1994) interacts with linguistic and nonlinguistic knowledge, i.e. how it correlates with the semantics-pragmatics distinction. Perhaps among the most important conclusions is that the phenomena classified under each of the tropes do not necessarily constitute a natural class but form rather a continuum which cross-cuts the semantics-pragmatics borderline.

Key Words: Cognitive poetics, cognitive semantics, Milton's 'Paradise Lost', figurative language, meaning in poetry.

\section{Introduction}

Cognitive semantics emerged in the 1980s as part of Cognitive Linguistics, a loosely structured theoretical movement that opposed the autonomy of grammar and the secondary position of semantics in the generativist theory of language.

Cognitive linguistics is a flexible framework rather than a single theory of language. It constitutes a cluster of many partially overlapping approaches rather than a single well-defined theory that identifies in an all-or-none fashion whether something belongs to Cognitive Linguistics or not (see Geeraerts, 2006, p. 2).

The difference between a cognitive semantic approach and a non-cognitive semantic one relates much to the difference between a maximalist and a minimalist understanding of lexical semantics. This takes many forms: It may relate to the old question of the borderline between word knowledge and world knowledge. It may involve the dividing line between semantics and pragmatics. It may surface as a methodological choice between a structure-oriented or a usage-oriented mode of investigation.

The literature on cognitive semantics contains a number of works that tried in various ways to maintain the distinction. Here, I like to define cognitive semantics as an 
approach that explicitly embraces a maximalist position: One in which the distinction between semantics and pragmatics is irrelevant, in which language is seen in the context of cognition at large, in which language use is the methodological basis of linguistics, at least in principle.

The leading ideas of a cognitive linguistic conception of language reflect a belief in the contextual, pragmatic flexibility of meaning, the conviction that meaning is a cognitive phenomenon that exceeds the boundaries of the word, and the principle that meaning involves perspectivisation.

The first idea inspires an investigation of how language use leads to change, and how the dynamism of meaning manifests itself in the structure of categories. The second idea points to a description of meaning structures and semantic mechanisms that go beyond the lexical level. The third idea motivates an exploration of the way in which word meaning involves seeing one thing in terms of another, i.e. how new concepts are related to existing ones, through metaphor and metonymy, or through the extension of a prototype.

Some might question the ability of cognitive semantics to live up to its ambition of providing a maximally contextualised description of meaning. However, cognitive semantic investigations show that this is not yet entirely the case, and that there is still some extra ground to conquer for the cognitive enterprise. In addition, the great number of scholars that are getting involved and the great number of publications produced in the field indicate that cognitive semantics is becoming the most popular framework for the study of lexical meaning in contemporary linguistics. 


\section{Cognitive Semantics: Some Major Theories}

\subsection{Image Schemas}

Lakoff and Johnson introduced the notion of 'image schema' in 1987 advancing a non-objectivist, experiential approach to the study of language and thought (Hampe, 2005, p. 1). Johnson (1987, pp. xiv, xvi) states that an image schema is a recurring dynamic pattern of our perceptual interactions and motor programmes that gives coherence and structure to our experience. Here the word 'experience' is to be understood in a very rich, broad sense as including basic perceptual, motor-programme, emotional, historical, social and linguistic dimensions.

One way in which embodied experience manifests itself at the cognitive level is in terms of image schemas. These are rudimentary concepts like 'contact', 'container' and 'balance', which are meaningful because they derive from and are linked to human preconceptual experience: Experience of the world directly mediated and structured by the human body. These image-schematic concepts are not disembodied abstractions, but derive their substance, in large, from the sensory-perceptual experiences that give rise to them in the first place (Lakoff, 1987, pp. 267-8).

Johnson (1987) and Lakoff (1987) argue that embodied concepts can be systematically extended to provide more abstract concepts and conceptual domains with structure. This process is called 'conceptual projection' (see Evans, 2007, p. 35). For example, they argue that conceptual metaphor is a form of conceptual projection. According to this view, the reason we can talk about being in states like 'love' or 'trouble' is because the abstract concepts 'love' and 'trouble' are structured and therefore understood by virtue of the fundamental concept 'container'. In this way, embodied 
experience serves to structure more complex concepts and ideas (also see Evan \& Green, 2006, p. 46).

Image schemas structure our bodily experience directly and our non-bodily experience via metaphor (Lakoff 1987, p. 453; Johnson 1987, p. 29). This definition clarifies the seemingly contradictory description of image schemas sometimes found: Image schemas are 'abstract' in one sense of that word, as they are schematic, but not 'abstract' in another sense of that word, as they are embodied (Croft \& Cruse, 2004, p. 44).

Examples of image schemas include: 'up-down', 'near-far', 'center-periphery', 'contact', 'path', 'containment', 'force', 'balance', 'counterforce', 'compulsion', 'blockage', 'diversion', 'attraction', 'removal', etc. (Clausner \& Croft 1999, p. 15).

All in all, image schemas are directly meaningful (being experiential and embodied), preconceptual structures, which arise from, or are grounded in, human recurrent bodily movements through space, perceptual interactions, and ways of manipulating objects.

\subsection{Mental Spaces}

The theory of mental spaces and its application to problems of reference and presupposition was first presented in 1978 at the Accademia della Crusca, in Florence. In later years, the approach was applied and extended to many areas that had not been foreseen, suggesting that mental spaces and mental space connections were far more pervasive than it had been first imagined (Fauconnier, 1994, p. xxxv).

The notion of mental spaces provides a model for the correspondence between linguistic processes and mental constructs. Mental spaces are constructs distinct from 
linguistic structures but built up in any discourse according to guidelines provided by the linguistic expressions. Linguistic expressions will typically establish new spaces via space-builders, expressions that may establish spaces that refer back to ones already introduced in the discourse. Space-builders may be prepositional phrases (e.g. 'in John's mind',' in 1929', 'from her point of view'), adverbs (e.g. 'probably', 'possibly', 'theoretically'), underlying subject-verb combinations (e.g. Peter believes, Mary hopes, George claims), etc.

Space-builders come with linguistic clauses, which typically predicate relations holding between space elements. Furthermore, the space-builder establishing space $\mathrm{X}$ will always establish it as included in some other space $\mathrm{Y}$, which would be its 'parent space', e.g.:

(1) Jane believes that in Japan most people are vegetarian.

In (1), the mental space $\mathrm{X}$ established by 'in Japan' is included in space $\mathrm{Y}$ (the parent space) established by 'Jane believes'.

A crucial property of language, cognitive constructions, and conceptual links, is the Access Principle (also called Identification Principle). This principle states that an expression which names or describes an element in one mental space can be used to access a counterpart of that element in another mental space. The following example will help to get an idea of how mental space configurations are built up. Suppose that we are engaged in a conversation about Shakespeare, and the following statement is made: 
(2) I think Shakespeare is on the table

This sentence brings in a frame from our pre-structured background knowledge about Shakespeare, as well as rich default information linked to the idealised cognitive model tied to this frame. The word 'think' is a space builder; it sets up a possibility space relative to the discourse base space at that point. The base space contains elements a (Shakespeare himself) and b (a play of Shakespeare) associated with the name 'Shakespeare', and presumably those elements have been linked to other frames by background knowledge and previous meaning construction in the conversation. The new sentence sets up a possibility space, within which a mental space is built whereby a play of Shakespeare is identified by the name 'Shakespeare' by virtue of the Access Principle. In other words, a play of Shakespeare is thought to be on the table, not Shakespeare himself, and this is all done by virtue of the access principle (see Fauconnier, 1994, p. 29; Stockwell, 2002, p. 97).

\subsection{Construal}

In talking about a scene, the speaker is faced with a number of choices. An important emphasis in the theory of construal is on the speaker's conceptualisation of scenes and the range of cognitive processes he utilises as evident in his use of language. A basic tenet of cognitive linguistics is that speakers can construe a scene in alternative ways (Saeed, 2003, 376).

According to Ferrando (1998, p, 69), construal contrasts with content in the sense that expressions that evoke the same content can nonetheless be semantically different because they apply alternate construal of that content. For example, while both 'shore' 
and 'coast' refer to the boundary between land and water, the former describes a scene from the water, while the latter describes a scene from the land (see, e.g., Fillmore, 1982, p. 121).

There are different aspects of construal in providing an explicit account of semantic phenomena. These are as follows (Langacker, 1993, pp. $448 \mathrm{ff}$.$) :$

1. Specificity: It is the degree of precision and detail with which a situation is chararcterised. Thus the following sentences describe the same event but with different degrees of specificity:

(3) a. The old man kicked the cat furiously.

b. Someone kicked the cat.

c. Someone did something.

2. Scope: It refers to those portions of active domains that a particular expression selects and exploits as the basis for its meaning, and that are most relevant for a particular purpose. In other words, an expression's scope is the extent of the conceptual content it evokes and depends on for its characterisation.

3. Prominence: An element can be prominent or salient in diverse ways. One of them is profiling. Every expression profiles some substructure within its conceptual base or scope. For example, 'eye' provides a base or scope for further concepts like 'iris', 'pupil', and 'cornea'. Two or more expressions may evoke the same content but differ semantically because of profiling different facets. 
4. Background: It is an ability to conceptualise two distinct structures in relation to one another to entertain them simultaneously but asymmetrically, so that one of them is of primary interest. One example is metaphor, where a source domain provides the background used for construing a target domain.

5. Perspective: It comprises diverse aspects such as 'vantage point', 'orientation', 'mental transfer', etc. For example, to choose to say 'John is in front of the tree' or 'John is behind the tree' depends on the speaker's 'vantage point', i.e. his/her position with respect to the content expressed.

6. Subjectification: An entity is said to be construed objectively or subjectively to the extent that it functions exclusively as the object or subject of conception. Langacker (1987, p. 132) states that it is also possible to subjectify reference to an entity. For example, examining a photograph, one could say 'That's me in the top row'. Here, an entity that is not the speaker, namely the physical image in the photograph, is described using a deictic expression 'me'. Another, more common example of subjectification is the construal implied when using certain spatial expressions that can leave a ground object unexpressed. A sentence like 'John is sitting across the table' can only refer to a situation where 'John' is sitting across the table from where the speaker is sitting.

7. Setting and participants: There is usually a tendency to organise a conceived situation in terms of a stable, inclusive setting, within which smaller participants occur and engage in relationships. Participants interact with one another in a certain way, and occupy some portion of a setting. 


\section{Paradise Lost}

'Paradise Lost' is an epic poem in blank verse. The poem was written by the $17^{\text {th }}$ century English poet John Milton (1608-1674). It was originally published in 1667 in ten books (sections in the manner of the division of Virgil's Aeneid) with a total of over ten thousand individual lines of verse. A second edition followed in 1674, in twelve books with minor revisions throughout and a note on the versification. It is considered to be Milton's major work that helped to solidify his reputation as one of the greatest English poets of his time.

The poem concerns the Biblical story of the Fall of Man: The temptation of Adam and Eve by the fallen angel Satan and their expulsion from the Garden of Eden. Milton's purpose, stated in Book I, is to 'justify the ways of God to men' (Bradford, 2001 p. 43).

The poem follows the epic tradition of starting 'in medias res' (Latin for in the midst of things), the background story being recounted later. Milton's story has two narrative arcs: One is of Satan and the other is of Adam and Eve. It begins after Satan and the other rebel angels have been defeated and banished to Hell. In Pandæmonium, Satan employs his rhetorical skill to organise his followers; he is aided by Mammon and Beelzebub. Belial and Moloch are also present. At the end of the debate, Satan volunteers to poison the newly created Earth and God's new and most favoured creation, Mankind.(see Wikipedia, 2013, 'Paradise Lost').

At several points in the poem, an Angelic War over Heaven is recounted from different perspectives. Satan's rebellion follows the epic convention of large-scale warfare. The battles between the faithful angels and Satan's forces take place over three days. Then, God creates the World, culminating in his creation of Adam and Eve. While God gave Adam and Eve total freedom and power to rule over all creation, He gave 
them one explicit command: Not to eat from the Tree of the knowledge of good and evil on penalty of death (Mitchell, 1984, pp. 5-10).

The story of Adam and Eve's temptation and fall is a fundamentally different, new kind of epic: A domestic one. Adam and Eve are presented for the first time in Christian literature as having a full relationship while still being without sin. They have passions and distinct personalities. Satan, disguised in the form of a serpent, successfully tempts Eve to eat from the Tree by preying on her vanity and tricking her with rhetoric. Adam, learning that Eve has sinned, knowingly commits the same sin. He declares to Eve that since she was made from his flesh, they are bound to one another so that if she dies, he must also die. In this manner, Milton portrays Adam as a heroic figure, but also as a greater sinner than Eve, as he is aware that what he is doing is wrong (Bradford, 2001, p. 76).

After eating the fruit, Adam thought that Eve was right in thinking that eating the fruit would be beneficial. However, they soon fall asleep and have terrible nightmares, and after they awake, they experience guilt and shame for the first time. Realizing that they have committed a terrible act against God, they engage in mutual recrimination.

Then, Adam and Eve both approach God to 'bow and sue for grace with suppliant knee', and to receive grace from God. Adam is shown a vision by the angel Michael, in which Adam witnesses everything that will happen to mankind until the Great Flood. Adam is very upset by this vision of humankind's future.

Adam and Eve are cast out of Eden, and Michael says that Adam may find 'a paradise within thee, happier far'. Adam and Eve also now have a more distant relationship with God, unlike the case in the Garden of Eden (For a detailed study of the poem, see Lewalski, 2003, pp. 444-490). 


\section{A Cognitive Semantic Analysis of 'Paradise Lost'}

\subsection{Image Schemas in 'Paradise Lost'}

\subsubsection{Landmark and Trajector}

Book I

Of Man's first disobedience, and the fruit Of that forbidden tree whose mortal taste

Brought death into the World, and all our woe, With loss of Eden, till one greater Man

Restore us, and regain the blissful seat,

The concepts of 'landmark' and 'trajector' are two key concepts in the image schema theory. The above extract contains three images that are based on these two concepts. The two concepts often explain cases where a clearly defined trajector (TR) leaves a spatially bounded landmark (LM).

The first image schema is that of 'first disobedience', i.e. Adam's disobedience, (TR) being highlighted out of a number of examples of man's disobedience (LM). It is worth noting that Milton's time is being provided here as the deictic centre because only from his time can Adam's disobedience be seen the first.

The second image schema is that of 'the forbidden tree whose mortal taste brought death to the World'. Here the poet presents a compound image schema of 'force' and 'containment'. This can be identified in terms of 'death' (TR) being forced into 'the World' (LM). Figure 1 is an imagistic representation of the two concepts:

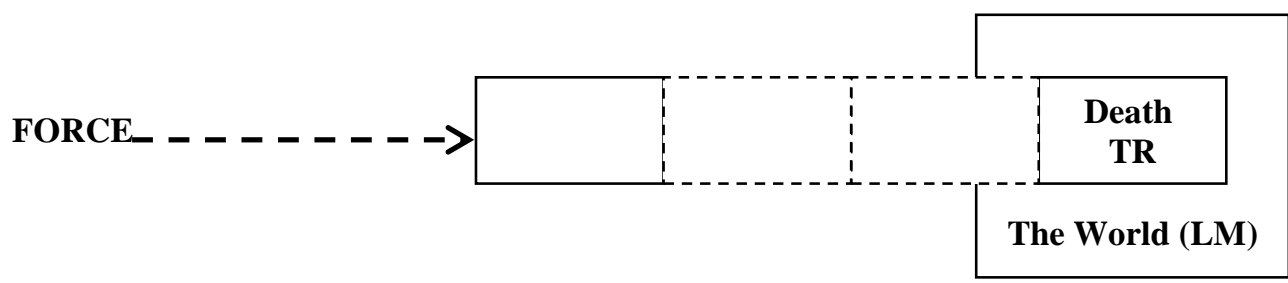


Figure 1: Compound Image Schema: Force and Containment

\section{Book IV}

Which way I fly is Hell; myself am Hell;

And, in the lowest deep, a lower deep

Still threatening to devour me opens wide, To which the Hell I suffer seems a Heaven.

This part of the poem exhibits two clear inseparable image schemas: Containment and vertical movement. The two images could be thought of as components of a single compound image schema. The speaker speaks of himself as being confined in 'Hell'. The containment image schema results from the sentence 'Which way I fly is Hell', in which a TR (I) is presented as being contained in an LM (Hell). The second component image is drawn in the sentence 'in the lowest deep, a lower deep still threatening to devour me opens wide', which gives depth to the place where the speaker is kept. The elements can be shown in the following figure:

\begin{tabular}{|c|}
\hline TR (I) \\
$\mathbf{1}$ \\
$\mathbf{1}$ \\
$\mathbf{1}$ \\
$\mathbf{I}$ \\
LM (Hell) \\
\hline
\end{tabular}

Figure 2: Compound Image Schema: Containment and Vertical Movement

\subsubsection{Complex Image Schemas: Force, Outward Movement, and Up/Down}




\section{Book I}

Say first-for Heaven hides nothing from thy view,

Nor the deep tract of Hell-say first what cause

Moved our grand parents, in that happy state,

Favoured of Heaven so highly, to fall off

From their Creator, and transgress his will

For one restraint, lords of the World besides.

Who first seduced them to that foul revolt?

Th' infernal Serpent; he it was whose guile, Stirred up with envy and revenge, deceived The mother of mankind, what time his pride Had cast him out from Heaven, with all his host Of rebel Angels, by whose aid, aspiring

To set himself in glory above his peers,

The lines above explain how Satan (The infernal Serpent) seduced Adam and Eve to disobey Almighty God, and thus fall off Heaven. The lines contain three inseparable image schemas that can be said to serve as components of a single complex image schema. The first image schema is that of 'the infernal Serpent' forcing Adam and Eve to get out of heaven. The second is that of Adam and Eve getting out of Heaven, i.e. outward movement. The third is that of Adam and Eve falling off the heaven, i.e. downward movement. The three image schemas are presented in the following figure:

The Infernal Serpent (Force)

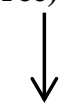

Our Grand Parents (TR) Heaven (LM 1)

Outside Movement

Our Grand Parents (TR)

Our Grand Parents (TR) Earth (LM 2) 
Figure 3: Complex Image Schema: Force, Up/Down, and Outward Movement

\section{Book V}

So quickened appetite, that I, methought, Could not but taste. Forthwith up to the clouds

With him I flew, and underneath beheld

The earth outstretched immense, a prospect wide

And various: Wondering at my flight and change

To this high exaltation; suddenly

My guide was gone, and I, methought, sunk down,

And fell asleep; but $O$, how glad I waked

To find this but a dream! Thus Eve her night

Related, and thus Adam answered sad.

Best image of myself, and dearer half,

The trouble of thy thoughts this night in sleep

Affects me equally; nor can I like

This uncouth dream, of evil sprung, I fear;

Yet evil whence? in thee can harbour none,

The lines above contain some important up and down movement image schemas as evident in 'up to the clouds With him I flew', 'underneath beheld The earth . . . ', and 'sunk down'. It is worth noting that the poem abounds with this type of image schema in particular; it prevails in more than one book of the poem. This is so because the poet has uppermost in his mind the image of Adams and Eve moving up to the Garden of Eden and then falling down to earth after eating the forbidden fruit.

\subsection{Mental Spaces in 'Paradise Lost'}

It is perhaps in place to say that the whole poem, including the title, represents a shift from the reality space or the reality world of Milton to a past space, namely that of 
Adam and Eve. In the following sub-sections, we will be exploring some of the manifestations and cognitive semantic values of this general transfer or shift.

\subsubsection{Reality Space and Projected Space}

\section{Book V}

Awake: The morning shines, and the fresh field

Calls us; we lose the prime, to mark how spring

Our tender plants, how blows the citron grove, What drops the myrrh, and what the balmy reed, How nature paints her colours, how the bee Sits on the bloom extracting liquid sweet. Such whispering waked her, but with startled eye

I rose as at thy call, but found thee not;

To find thee I directed then my walk;

And on, methought, alone I passed through ways

That brought me on a sudden to the tree

Of interdicted knowledge: fair it seemed,

Much fairer to my fancy than by day:

And, as I wondering looked, beside it stood

One shaped and winged like one of those from Heaven

This extract represents a shift from the reality space (the reality world of Eve) to a counterfactual, projected space (a dream by Eve). A detailed description of the dream is then provided. There is yet another shift from the built space of the dream to another counterfactual space that is created by the space builder 'methought' (i.e. I thought). Here Eve is talking to Adam about a dream she had, and she tells him about what she thought about part of the dream within the dream.

The verb 'seem' in 'fair it seemed' sets up a mental space that is different from the reality space, specifically one that usually exists in the speaker's mind. In other words, it describes a scene as seen by the speaker, which might be different from what the scene actually was; therefore, the truth of which is questionable. This shift from the reality space can be seen as a requirement of accuracy or objectivity of description, 
since, with the use of 'seem', the speakers presents a scene or event as he/she sees or understands it (cf. Albayati, 2012, p. 252).

\subsubsection{Identification Principle, Trigger, and Target}

\section{Book I}

Regions of sorrow, doleful shades, where peace

And rest can never dwell, hope never comes

That comes to all, but torture without end

Still urges, and a fiery deluge, fed

With ever-burning sulphur unconsumed.

Such place Eternal Justice has prepared

For those rebellious; here their prison ordained

In utter darkness, and their portion set, As far removed from God and light of Heaven As from the centre thrice to th' utmost pole.

Oh how unlike the place from whence they fell!

There are in language some indirect strategies that we can use in order to make reference to entities or persons. It is possible, for example, to refer to a representation of someone using his/her name, so that looking at a photograph of, say, Nancy, one might say 'Nancy looks really young'. Here 'Nancy' refers to the picture of Nancy, who might not look young in reality. Fauconnier (1994, pp. 3-4) uses the terms trigger to refer to the person in reality, i.e. 'Nancy' in our example, and target to refer to the picture or image of the person (i.e. what is being described). This is all done through a cognitive semantic principle which is termed 'Identification Principle' (loc. cit.).

In the example above, human beings are referred to in term of some mental states they go through. Namely 'peace' and 'rest'. Human beings and 'peace', 'rest', and 'hope' are related by a 'pragmatic function', a concept that establishes a link between the 'trigger' and 'target', namely a metonymy relation . 
Technically speaking, we have here an example of a trigger (peace, rest, and hope) that is related to a target (human beings) by a connector (metonymy relation). These are actually two mental spaces that are linked by some pragmatic function. All these cognitive semantic concepts can be presented diagrammatically in the following figure:

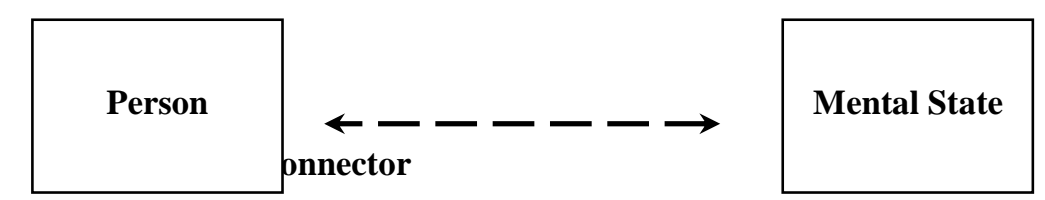

Part-Whole Relation

Trigger $=$ Human Beings

Target $=$ 'Peace',

'Rest', 'Hope'

Figure 4: Trigger, Target, and Connector

\subsubsection{Personification, Metaphor and Role-Value Relation}

\section{Book III}

Our two first parents, yet the only two

Of mankind in the happy garden plac'd

Reaping immortal fruits of joy and love,

Uninterrupted joy, unrivall'd love,

In blissful solitude; he then survey'd

Hell and the gulf between, and Satan there

Coasting the wall of Heaven on this side Night

Fauconnier (1994, p. 40) distinguishes between roles and values in mappings between spaces. A role is a linguistic description describing a category, while a value is an individual that can be described by that category. Roles can be a category or type with various instances or tokens. Accordingly, 'car' is a role, since there are many instances (values) of car, e.g. Mercedes, BMW, and Toyota. 
A central insight in cognitive semantics is that many puzzling semantic phenomena are the result of the fact that a value or a role in one space can be described by a value or a role in another totally different space (cf. Croft \& Cruse, 2004, p. 34; Evans \& Green, 2006, p. 381; Fauconnier, 1994, pp. xxv, 29; Stockwell, 2002, p. 97). Personification and metaphor are two by-products of such a mapping. In 'happy garden', which is an example of personification, there is a non-human role (garden) that is being described in terms of a value (happy) within human positive qualification role.

Likewise, in 'the fruits of joy and love', which is a metaphor, there is a mapping of values of a human role, namely 'joy' and 'love', onto a non-human role, namely 'fruits'.

The odd matching exemplified by the two instances above provides a cognitive semantic explanation of some important figures of speech, which in turn unfolds some of the hidden aspects of poetic creativity.

\subsection{Construals in 'Paradise Lost'}

\subsubsection{Deictic Expressions and Referential Opacity}

\section{Book VI}

At thy request, and that thou mayest beware

By what is past, to thee $I$ have revealed

What might have else to human race been hid;

The discord which befel, and war in Heaven Among the angelick Powers, and the deep fall Of those too high aspiring, who rebelled With Satan; he who envies now thy state, Who now is plotting how he may seduce Thee also from obedience, that, with him Bereaved of happiness, thou mayest partake His punishment, eternal misery;

The lines above abound with deictic expressions whose meanings can be inferred only with reference to the speaker's context, i.e. the deictic centre. First, the sentence 'I 
have revealed' describes an action that is connected to the time of speaking, as it appears in the present perfect tense. In other words, the action can be considered to be linked to the present time only when seen from the speaker's time of speaking. From the listener's point of view, the action is past perfect. Second, what 'now' stands for in 'he who envies now thy state' and 'Who now is plotting' can only be identified relative to the speaker's time. With such expression, Milton provides the events and conversation like cinema shots. A major problem with Milton's 'Paradise Lost', being an exceptionally long poem, is the fact that it abounds with deictic expressions whose referents are tiresome to trace. To give but one representative example, the extract above, which is only eleven lines, contains two instances of 'thy', two of 'thou', two of 'thee', and four different forms of the third person singular pronoun. Moreover, sometimes one may need to go back as far as two pages in order to identify the referents of some of the pronouns. This phenomenon gives rise to the semantic and pragmatic problem of referential opacity.

\subsubsection{Vantage Point and Orientation}

\section{Book VIII}

Abstract as in a trance, methought I saw, Though sleeping, where I lay, and saw the shape

Still glorious before whom awake I stood:

Who stooping opened my left side, and took From thence a rib, with cordial spirits warm, And life-blood streaming fresh; wide was the wound, But suddenly with flesh filled up and healed: The rib he formed and fashioned with his hands; Under his forming hands a creature grew, Man-like, but different sex; so lovely fair, That what seemed fair in all the world, seemed now Mean, or in her summed up, in her contained And in her looks; which from that time infused Sweetness into my heart, unfelt before, And into all things from her air inspired The spirit of love and amorous delight. She disappeared, and left me dark; I waked 
Vantage point is all about the speaker's spatiotemporal position with respect to the content expressed. The whole point can be seen as an example of 'mental transfer' whereby the original speaker, the poet in this case, presents one of the characters as the speaker on his behalf and provides his/her spatial and/or temporal location as the centre for the events being described. However, for the sake of simplification and in line with a method that is common in discourse analysis, we shall take the speaker in the poem as the deictic centre, i.e. Adam rather than Milton. In that case, we will have provided two lines of argument: with and without mental transfer.

In the lines above, the speaker (i.e. Adam) provides a detailed account of how Eve was created out of his rib, and in doing so, he describes the whole event relative to his vantage point, i.e. his spatial and temporal context. The clause 'where I lay' established the speaker's position as the point from which all events are seen. This point is vague to reader since Milton cannot visualise it based on prior experience or encyclopaedic knowledge, to use cognitive semantic terms, as it is somewhere that can never been seen in this world.

The post-modifying element 'before whom awake I stood' and the phrase 'my left side' are worth some elaboration. The same item can be observed and described from a number of different vantage points, resulting in different construals which may have overt consequences. Many expressions undeniably invoke a vantage point as part of their meaning. The words 'behind' and 'left' rely on the vantage point to specify a TR's location vis-a-vis an LM. Of course, the vantage point assumed here is the speaker's actual location. However, we, the readers of this poem in particular, can easily adopt a 'fictive vantage point' and imagine what the scene would look like from there. 
Another cognitive semantically important issue here is whether the shape which the speaker says he stood before has an inherent or intrinsic orientation such that the side of the shape faced by the speaker is its front side, regardless of the speaker's relative position (cf. Levinson, 1983, p. 82).

The word 'before' in the clause 'unfelt before' indicates two important construal operations: First, the line makes it clear that the poet refers to a period of time relative to the speaker's time. Technically, he presents the Adam's time as the deictic centre, to which the other periods or points of time referred to in this line have to be anchored. This is not accidental and can be seen as a means of actualising objectivity in description. The analyses above reflect that the poet distances himself from the spatiotemporal environment of this part of the poem, as he is referring to a context that is impossible to access or envisage.

\subsubsection{Categorisation}

\section{Book VII}

And God made two great lights, great for their use

To Man, the greater to have rule by day, The less by night, altern; and made the stars, And set them in the firmament of Heaven To illuminate the Earth, and rule the day

Categorisation is a key concept in the construal theory and implies two major construal operations, namely judgment and comparison. It involves comparison of a certain experience to prior experiences and judging it to belong to the class of prior experiences to which the linguistic expression has been applied. There are many ways in which a situation can be compared and judged to be like a prior experience.

The lines above contain a couple of example of categorisation. There is, first, the sentence 'God made two great lights', where the sun and the moon are categorised as 
lights. Outside cognitive semantics, this is but an example of metaphor, but in cognitive semantics terms, this is a linguistic expression whose meaning in this particular context is a product of two important conceptual processes, viz, comparison and judgment. An important semantic phenomenon is also in operation here, namely metonymy. Light is part of what the sun and the moon provide.

Also the poet utilises the flexibility of framing within categorisation by subsuming the sun and moon within a different frame, thus, in effect, redefining the frame of 'light'. In other words, the poet offers a reconceptualisation of the category 'light'.

The poet states that God has created the stars and 'set them in the firmament of Heaven and illuminate the earth'. This is actually a personal conceptualization of the reason why Almighty God has created the stars. This has to do with a general cognitive principle whereby human beings identify the abstract in terms of the concrete, the unknown in terms of the known, and the less familiar in terms of the more familiar (see Taylor 1989, p.132).

\subsubsection{Subjectification versus Objectification}

\section{Book IX}

Of all God's works, Creature in whom excelled Whatever can to sight or thought be formed, Holy, divine, good, amiable, or sweet! How art thou lost! how on a sudden lost, Defaced, deflowered, and now to death devote! Rather, how hast thou yielded to transgress The strict forbiddance, how to violate The sacred fruit forbidden! Some cursed fraud Of enemy hath beguiled thee, yet unknown, And me with thee hath ruined; for with thee Certain my resolution is to die: How can I live without thee! how forego Thy sweet converse, and love so dearly joined, To live again in these wild woods forlorn! Should God create another Eve, and I Another rib afford, yet loss of thee 
Would never from my heart: no, no!I feel

The link of Nature draw me: flesh of flesh,

Bone of my bone thou art, and from thy state

Mine never shall be parted, bliss or woe.

So having said, as one from sad dismay

Two lines of argument can be picked in the course of analyzing this part of the poem. First, the chain of questions presented in lines 4 to 8 exemplifies a subjective construal on the part of the poet. This would be the case if and only if the speaker was taken to be the poet himself. The speaker is using the deictic personal pronoun 'thou', and thus defining his identity relative to the speech act situation, i.e. raising questions with no expectation to get any answer(s).

It is also possible to subjectify reference to an entity. This happens when certain spatial or temporal expressions are used relative to the speaker's position, and the poem abounds with such expressions (see, e.g. 'before' in 4.3.2).

However, the same lines could be said to involve objectification; since the poet could be said to present himself independent of the speech act situation, but this would be the case if and only if the interlocutors were taken to be Adams and Eve.

\section{Summary and Conclusions}

The cognitive semantic analysis of Milton's 'Paradise Lost' has yielded various conclusions, the most prominent of which are the following:

1. The relation between the so-called 'trigger' and 'target' cross cuts the semanticspragmatics borderline, as it is a cognitive association which entirely relies on the speaker's, the poet in our case, conceptualisation and categorisation ability. This particular ability derives from the poet's prior experience and encyclopaedic 
knowledge, hence the difference between poets in effectiveness in expressing the same feeling, experience, or concept.

2. The concepts of 'trajector-landmark', 'confinement', 'container', 'force', 'highlow', and 'up-down' predominate throughout the poem as they go with the main event described in the poem, namely that of Adam and Eve being contained in Eden, and then their being forced by Satan to get out of it; something that Milton has uppermost in his mind in every single part of the poem. This indicates that a poet's language can reflect his conceptualisation of a certain event or experience.

3. Milton's being subjective in his account for certain events is exemplified by his use of some worlds and concepts, whose truth is questionable. This evident in Milton's recurrent use of space-builders that shift the reader from the reality world to worlds where what he states might be true. However, this can also exemplify Milton's objectivity in narrating events for which he lacks adequate evidence.

4. Metaphor, personification, metonymy, etc. are all conceptual strategies that are indispensable in the complex process of meaning construction. They are by no means literary devices that are confined to literary genres, a fact that brings both figurative language and literal language to common ground.

5. A great deal of poetic creativity can be ascribed to the poet's cognitive semantic competence in establishing conceptual links between different pairs of concepts, usually abstract and concrete or unfamiliar and familiar, with the aim of making them conceivable for the reader. Perhaps this is why a single line of verse so often summarises a really complex concept or idea. 
6. So often Milton distances himself from the events and the content expressed by providing deictic centres relative to a character in the poem, perhaps for reasons of objectivity, especially in contexts that are inaccessible to the poet himself.

\section{References}

- Albayati, A. F. (2012). A cognitive semantic study of some Neo-classical and Romantic poems. (Unpublished doctoral dissertation). University Koya, Iraq.

- Bradford, R. (2001). The complete critical guide to John Milton. London: Routledge

- Clausner, T. C., \& Croft, W. (1999). Domains and image-schemas. Cognitive Linguistics 10, pp. 1-31.

- Croft, W., \& Cruse, D. A. (2004). Cognitive linguistics. Cambridge: Cambridge University Press.

- Evans, V. (2007). A glossary of cognitive linguistics. Edinburgh: Edinburgh University Press.

- Evans, V., \& Green, M. (2006). Cognitive linguistics: An introduction: Edinburgh: EdinburghUniversity Press.

- Fauconnier, G. (1994). Mental spaces. Cambridge: Cambridge University Press.

- Ferrando, I. N. (1998). A cognitive semantics analysis of the lexical units at, on, and in in English. (Unpublished doctoral dissertation). Universitat Jaume I: Department de Filologia Anglesa I Romanica.

- Fillmore, C. (1982). Frame semantics. In The Linguistic Society of Korea (Ed.). Linguistics in the Morning Calm (pp. 111-137). Seoul: Hanshin Publishing Company. 
- Geeraerts, D. (2006). A rough guide to cognitive linguistics. Cognitive Linguistics Research, 34, 1-28.

- Hampe, B. (2005). Image schemas in cognitive linguistics: Introduction. Cognitive Linguistics Research, 29, 1-12.

- Johnson, M. (1987). The body in the mind. Chicago: University of Chicago Press.

- Lakoff, G. (1987). Women, fire and dangerous things: What categories reveal about the mind. Chicago: University of Chicago Press.

- Langacker, R. W. (1993). Universals of construal. Proceedings of the Annual Meeting of Berkeley Linguistic Society, 14, Berkeley: BLS, 447-463.

- Langacker, R. W. (1987). Foundations of cognitive grammar vol. 1: Theoretical prerequisites. Stanford: Stanford University Press.

- Lewalski, B. K. (2003). The life of John Milton: A critical biography. (Revised Edition). London. Blackwell Publishing.

- Mitchell, R. (1984). John Milton's Paradise Lost. (n.p.): Barron's Education Series, Inc.

- Mitlon, J. Paradise Lost. Retrieved on May $2^{\text {nd }}, 2014$ from http//www.planetpdf.com.

- Saeed, J. I. (2003). Semantics (2 ${ }^{\text {nd }}$ ed.). Malden, MA: Blackwell Publishing.

- Stockwell, P. (2002). Cognitive poetics: An introduction. London: Routledge.

- Taylor, J. R. (1989). Linguistic categorization: Prototypes in linguistic theory. Oxford: Oxford University Press. 


\section{خلاصة البحث الموسوم}

\section{(تحليل دلالي إدراكي لقصيدة "القردوس المفقود" لملتن)}

إن حقل معالجة اللغة الطبيعية قد قطع أثواطا كبيرة في المعالجة الحاسوبية للغـة القياسية، إلا أن معالجة لغة الثـعر ماز الت تشكل صعوبة بالغـة. لقد بـات من الطبيعي في سعينا إلى فهم اللغة البشرية أن نستجمع معاني الكلمـات منفردة وونضعها في إطـار وحدات دلالية أوسع تشكل في مجملها ما يمكن أن يفهم على أنه فكرة كاملة. أما فهم قصيدة ما فتحتاج إلى معالجة تأويلية وتفعيل استر اتيجيات عقلية مختلفة لاستيعاب الكلمات الواردة فيها.

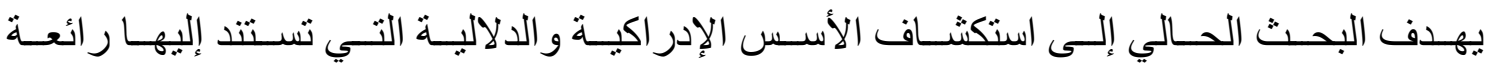
الثاعر الإنكليزي ملتن "الفردوس المفقود" بناءً على بعض الأطر النظرية وأسس تحليل المعطيات وفق الآليات التجريبية. تفترض الدر اسة أطروحة مفادها أن الأسـاليب البلاغيـة ليست أدو ات لغويـة تقتصر وظيفتها على الزخرفة و أداء غرض أدبي، بل هي أدوات عقلية لا منـاص من اللجوء إليها لأجل تحقيق الإدر الك. بعد رصدها لمكانـة الأسـاليب البلاغية في البنيـة الإدر اكية للإنسـان، بدأت الدر اسات الحديثة تبتعد بخطى و اثقة عن الر أي القائل بأن اللغة المجازية تجسد انزياحا عن العرف اللغوي السائد. من المسائل التي لطالما تطرح في الأدب و التي آثرنا تناولها هنـا هو مدى تفاعل مفهوم مـا يسميه جبز ( \99 (1) ب"شـاعرية العقل" مـع المعرفة اللغويـة والمعرفة الالغويـة. أي العلاقة بينها وبين الجانبين الدلالي والتداولي في اللغة. إن من أبرز مـا توصل إليه البحث هو أن الظواهر الدلالية الإدر اكية التي تشكل دعامة عبارة مجازية ما لاتثكل صنفا طبيعيا داخلا في تكوين العبارة بقدر مـا هي مزيج من المو اد الدلالية والتداولية التي لا مناص من مزجها لإظـاهر العبارة الهجازيـة بالثكل

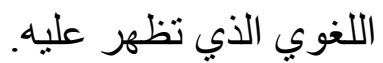

